\title{
Estimating Degradation Factorby Performance Ratio of Rooftop Solar PV Plant
}

\author{
Rajesh Kumar Prakhya, K.Shashidhar Reddy, Ch. Lokeshawar Reddy
}

\begin{abstract}
This paper diagnostically appraises the debasement thing of the lattice tied housetop daylight based Photovoltaic plant. The impact of rot and plant via and large execution are assessed and dissected for $20 \mathrm{kWp}$ sun photograph Voltaic plant appointed on EEE Block housetop in CVR college of Engineering. The debasement appraisal is done bodily from the plant insights separated from internet-interface for the year 2015 and 2016. As an critical boost in this assessment, the plant's standard typically speakme execution percentage is decided for the two revolutionary years. within the later strengthen the quantity change in the plant standard usually speaking execution Ratio's are decided. This appraisal widely recognized that corruption of the plant regular by means of and huge execution is high in mid 12 months resulting from prolonged surrounding temperature. The debasement is resolved to be over the pinnacle in may additionally moreover and less in February. The notion procedures in this type of by means of and huge in preferred execution are broke down. inside the wake of considering the results, it is prescribed that plant must be saved up and inspected at intermittent spans for ventured ahead sizeable execution.
\end{abstract}

keywords:- Degradation thing, Grid-tied SPV Plant, Panel corruption, , overall performance Ratio (PR),overall performance Metrics, sun insolation, system performance.

\section{PRESENTATION}

The quality system to create power fromSolar PV module is bymaking utilization of photograph-Voltaicprinciple. on this methodthe solar orientated insolation is legitimately changed into DC electric powerfromthe solar PV cellular. single daylight based PV cellular producessmall quantum of electrical power. finally, to producelarge measure of electrical vitality, sufficient range of daylight based PV cells/moduleshave to be related both in arrangement or parallel setup.

Lattice tied SPV frameworks are extensively being utilized in view of their personal focal factors. electricity introduction bygrid connected SPV plant ought to be supervisedaccurately for healthieroperation of plant and available belongings [1-4]. SPV plant life execution, can'tbe expected efficaciously by means of the degree of vitality producedby the SPV plant over a selected time-frame. electric energy produced bySPV power plant is legitimately relative to the quantum of sun based insolation encroaches on the outdoor of SPV cluster. sun based Irradiation might not be uniform on always. sun primarily based radiation is high in summer season, better in iciness season and nevertheless less in stormy season. in this way, watching for

Rajesh Kumar Prakhya, Assoc. Professor, EEE Department, CVR College of Engineering, Hyderabad, India. (rajeeecvr@gmail.com)

K.Shashidhar Reddy, EEE Department,CVR College of Engineering, Hyderabad, India. (shashidhar.kotha5@gmail.com)

Ch. Lokeshawar Reddy, Assoc. Professor, EEE Department, CVR College of Engineering, Hyderabad, India. (reddy.lokeshwar @ gmail.com)
Revised Manuscript Received on July 18, 2019.

SPVplant capability dependent on quantum of electrical powerproduced with the aid of it is off base. on this way, to evaluate the SPV plants in widespread execution, extremely good measurements are primary. regular execution Ratio (PR) is big measurement, it's far visible with the asset of the PV business execs to discover the SPV plant preferred by using and large execution.

Climatic circumstances like inordinate temperature and radical mugginess have horrendous affect on through and massive execution and consistency of the SPV modules. but the module regular by means of and massive execution, essential by using and large execution of inverter is additionally a colossal aspect which prominently influences the overall device everyday execution and behavior. other than temperature, numerous components which effect the overall execution of SPV plant are sunlight based insolation, concealing impact, effect of weather, tempo of wind, load mis-stable, earth/dust on SPV exhibit, Accuracy of greatest electricity aspect following , misfortunes like Array keep onto misfortunes, heat misfortunes and $\mathrm{DC}$ to $\mathrm{AC}$ transformation misfortunes, and thousands of others. SPV trade authorities want to comfortable every affecting factor of interest and its effect on plant elegant conventional usually execution. [5-6].

Ordinary execution of the SPV cluster diminishes at faster charge than anyone of a sort system, as modules are supplied to direct climate conditions. In cutting-edge, corruption of PV Module is normally intemperate inside the fundamental $\mathrm{yr}$ as module is presented to the solar primarily based mellow for the primary time. Later it balances out additives influencing the tempo of rot are, occurrence of the feel applied underway, pressing of solar cells, strategy for assembling modules and daylight based mobile age.

thrilling additives that effect the debasement are, radical breezes, soil, dirt, day off, staining, cover deserts, mechanical pressure, cellular contact breakdown. explicit significant issue is breakage of module embodiment.

One of the fundamental additives to be stated proper ideal right here is, most of the people of the modules might not corrupt at equivalent charge. The fee of rot of one module isn't take care of charge of debasement of each specific module. Occasional remodel and review have to be carried out to pick out up the great results from the SPV plant over longer length.

On this paper, component II depicts the SPV plant region and bounds of the sub-plant life set in the net website online page. degree III in certainty discloses the way to envision

Published By:

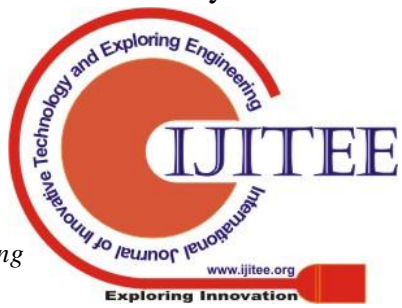


execution Ratio of community tied SPV plant. Estimation of rot component with the beneficial treasured asset of the usage of PR is also alluded to in component in this phase. stage IV methodicallly dissects the influences and talk on SPV Plant regular commonly talking execution, corruption element place $\mathrm{V}$ examines the ends went with the asset of references.

\section{DETERMINATIONS OF SPV PLANT}

Determinations and organization of every framework related SPV plant depends on upon such lots of factors like weather situations, near to stack conditions, nature of the thousands, best name for and loads of others. The topographical guidelines of net website web page on the web/plant determine the ordinary tilt mind-set of SPV modules.

\section{A. region of the plant}

The lattice linked SPV plant for the investigations is located on the CVR university of Engineering housetop, Vastunagar, Mangalpalli, Ibrahimpatnam, Hyderabad, the web site are 17.200 N, 78.six hundred E one after the other. The elevation of the siteis 545meters over the sea level.

\section{B. Limits Of image Voltaic Plant}

The maximum intense limits of various lattice connectedPV sub-flowers at the housetops of variousindependent systems in CVRCE are regarded in desk Iwith the date of initiation of the vegetation

table I. Details of Sub Plants, Their Capacities

\begin{tabular}{|l|l|l|l|}
\hline $\begin{array}{l}\text { Name of the Sub } \\
\text { Plant }\end{array}$ & $\begin{array}{l}\text { Location of } \\
\text { the Plant }\end{array}$ & $\begin{array}{l}\text { Installed } \\
\text { Power }\end{array}$ & $\begin{array}{l}\text { Date of } \\
\text { Commenc } \\
\text { ement of } \\
\text { Plant }\end{array}$ \\
\hline CVR PG Block & EEE Block & $120 \mathrm{kWp}$ & $\begin{array}{l}03-03- \\
2014\end{array}$ \\
\hline Single Axis Tracking & Main Block & $40 \mathrm{kWp}$ & $\begin{array}{l}18-01- \\
2015\end{array}$ \\
\hline Library & Library Block & $20 \mathrm{kWp}$ & $\begin{array}{l}23-10- \\
2014\end{array}$ \\
\hline $\begin{array}{l}\text { Single Axis Polar } \\
\text { Tracking }\end{array}$ & Main Block & $40 \mathrm{kWp}$ & $\begin{array}{l}11-03- \\
2015\end{array}$ \\
\hline CVR CS Block & CSE Block & $60 \mathrm{kWp}$ & $\begin{array}{l}22-10- \\
2015\end{array}$ \\
\hline CVR New & First Year & $80 \mathrm{kWp}$ & $\begin{array}{l}03-03- \\
2016\end{array}$ \\
\hline $\begin{array}{l}\text { Overall Plant } \\
\text { Capacity }\end{array}$ & & $\mathbf{3 6 0 k W p}$ & --- \\
\hline
\end{tabular}

The vital electric devices that are required for the framework related SPV flora are: SPV Modules (Array), sun Cables (AC and DC), Grid associated String Inverters, Junction receptacles, essential Switchgear, internet Metering (Bi-directional electricity meter), lighting apparatuses Arrestors, Earthing at proper spots. the full device, Telangana state. The geological Lattitude and Longitude of and Date of Commencement of Plant

introduced substances and devices are as in challenge with the IEC 61724 guidelines given via MNRE [7].

String inverter is the power automated device, that modifications the DC electricity produced thru sun modules into three-degree AC electric energy at percent. Fig. 1 demonstrates the $20 \mathrm{~kW}$ framework tied REFUsol 008K$020 \mathrm{~K}$ string inverter is enlisted in this matrix tied SPV plant. At popular temperature occasions, its maximum intense productiveness is $98.2 \%$. For each $20 \mathrm{~kW}$ showcase one honest-minded string inverter is charged. desk II. recommends the opposite crucial inverter records as given through making use of the maker.

In simple phrases SPV cluster is characterized because the association/parallel association of different sunlight based totally forums relying upon framework setup dependent on voltage prerequisite at the inverter input terminals. Kohima electricity Pvt. Ltd. has provided the sun oriented modules utilized in this plant. KE-60-M250 is the module specialized code. The most excessive DC electric strength added by means of the module is $250 \mathrm{Wp}$ at STC conditions (250C ambienttemperature, $1000 \mathrm{~W} / \mathrm{m} 2$ Irradiation, A.M is 1.5). one-of-a-kind parameters of sun board are indicated in TableNo III. [8].

TABLE II.

DETAILS OF GRID INTEGRATED REFUSOL 020K SOLAR STRING INVERTER

\begin{tabular}{|l|l|}
\hline & REFUsol 020K \\
\hline DC DATA & \\
\hline Recommended Max. PV Power, kWp & 21.6 \\
\hline MPPT Range & $480 \mathrm{~V}-850 \mathrm{~V}$ \\
\hline DC Start Voltage & $350 \mathrm{~V}$ \\
\hline Max. DC Voltage & $1000 \mathrm{~V}$ \\
\hline Max. DC Current & $41 \mathrm{~A}$ \\
\hline MPP Trackers & 1 \\
\hline AC DATA & \\
\hline Rated AC Power & $19.2 \mathrm{kVA}$ \\
\hline Max. AC Active Power & $19.2 \mathrm{~kW}$ \\
\hline Rated Power factor & 1 \\
\hline Max. AC current & $3 \mathrm{X} \mathrm{29}$ \\
\hline Distortion factor THD & $<1.8 \%$ \\
\hline Max. efficiency & $98.20 \%$ \\
\hline European efficiency & $97.80 \%$ \\
\hline
\end{tabular}

REFUsol $008 \mathrm{~K}-020 \mathrm{~K}$
For medium-sied to megowott instollat

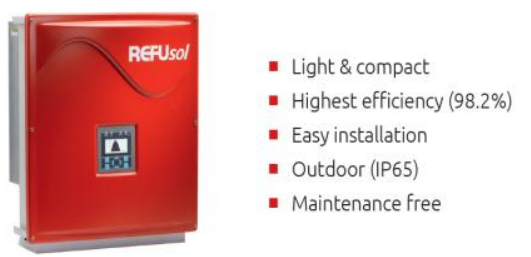

Fig.1REFUsol 008K-020K string inverter

Published By: Blue Eyes Intelligence Engineering 
As with regards to the format, for each $20 \mathrm{kWp}$ inverter, we require 80 no's of $250 \mathrm{kWp}$ sun based boards. moreover these eighty modules have associated in four parallel strings. subsequently, 20 PV modules are associated in accumulation for each string of the given inverter. On location picture of $20 \mathrm{~kW}$ housetop framework - tied SPV plant authorized on Library square is demonstrated in Fig.2. blessing examination on generally speaking execution proportion and debasement issue is completed on $20 \mathrm{kWp}$ lattice related SPV plant charged on the zenith of library.

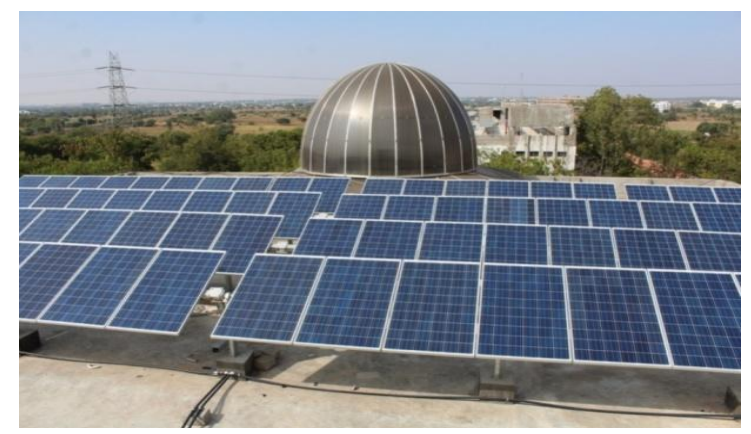

Fig.2.20kWp Solar PV Plant on Library Block of CVRCE

TABLE.III

SPECIFICATIONS OF SOlar MOdUle KOHIMA ENERGY

PVT. LTD.

\begin{tabular}{|c|c|}
\hline $\begin{array}{l}\text { STC-Irradiance of } 1000 \mathrm{~W} / \mathrm{Sq} . \mathrm{m} \text { at } \\
25^{\circ} \mathrm{C}\end{array}$ & KE-60-M250 \\
\hline Maximum Power $\left(\mathrm{P}_{\max }\right)$ & $250 \mathrm{~W}$ \\
\hline Maximum Power Voltage $\left(\mathrm{V}_{\mathrm{mp}}\right)$ & $31.44 \mathrm{~V}$ \\
\hline Maximum Power Current $\left(\mathrm{I}_{\mathrm{mp}}\right)$ & $7.95 \mathrm{~A}$ \\
\hline Open circuit Voltage $\left(\mathrm{V}_{\mathrm{oc}}\right)$ & $37.86 \mathrm{~V}$ \\
\hline Short Circuit Current $\left(\mathrm{I}_{\mathrm{sc}}\right)$ & $8.69 \mathrm{~A}$ \\
\hline Fill Factor & $75.98 \%$ \\
\hline Module Efficiency $\left({ }^{n}\right)$ & $15.40 \%$ \\
\hline $\begin{array}{l}\text { Nominal Operating Cell Temperature } \\
(\text { NOCT })\end{array}$ & $45+2$ \\
\hline Temperature Coefficient of Isc $(\alpha)$ & $0.04 /{ }^{0} \mathrm{C}$ \\
\hline Temperature Coefficient of Voc ( $\beta$ ) & $-0.32 /{ }^{0} \mathrm{C}$ \\
\hline Temperature Coefficient of Pmax (Y) & $-0.45 /{ }^{0} \mathrm{C}$ \\
\hline Cells per module & 60 \\
\hline Cell type & $\begin{array}{l}\text { Multi - } \\
\text { Crystalline } \\
\text { Silicon }\end{array}$ \\
\hline Cell Dimensions & $\begin{array}{l}156 \text { m.m X } 156 \\
\text { m.m }\end{array}$ \\
\hline
\end{tabular}

\section{PLANT METRICS(PR \& DEGRADATION)}

\section{A. Execution Ratio (PR)}

$\mathrm{PR}$ is one of the noteworthy metricto be determined for lattice tiedSolar image voltaic flora in occasional interims. the precise articulation to assess PR is given underneath.

$\mathrm{PR}=\mathrm{AC}$ power available at \%/Nominal power

The articulation for Nominal electricity =

In-aircraft solar Irradiation (in $\mathrm{kWh} / \mathrm{m} 2$ ) X module effectiveness at STC $X$ general active PV territory (in m2)(1)
PRis for the most element assessed for a 12 months to get total concept concerning the plant. PRcancalculated on daily, week after week, or month to month premise. In light of the time of intrigue, equivalenttime span has tobe supplied. In-aircraft sun Irradiation, Module productivity and active PV location are to be had in the denominator of the observational equation. Out of 3 parameters, the estimation of board proficiency is picked from nameplate critiques given by means of the board maker. Dynamic territory is decided through using vicinity of each board and range of forums. while In-aircraft sunlight based totally radiation of the plant is predicated on severalphysical parameters like encompassing temperature, sun powered board temperature, dirt, showcase capture misfortunes, midway shading,atmospheric conditions, and so forth. along those traces, assessment of PR assesses all of the above elements expressed in advance.therefore, the very last fabricated from all of the those additives can be repeated in PR computation. SPV plant is idea to be in superb working situation, if the decided PRvalue is near the $100 \%$.

Numerous Steps to evaluate the PR of the SPV plant bodily are as in line with the following:

- Decide the length of assessment (finest fine time period is finished time table a yr).

- Active PV spot of plant need to be processed via strategies for making use of manner of significant type of modules connected in PV showcase.

- Collect the measurements around PV board execution from maker's datasheets.

- Collect electric powered managed energy (AC) to be had at percentage of the plant from the inverter net statistics interface.

- From Pyranometer cozy the planned solar insolation esteems.

Ordinary typically speakme execution Ratio is the best measurement to choose the overall with the aid of and massive execution of differing SPV plants at severa regions impartial of climate and climate conditions. specialty from the hypothetical preferred normal execution Ratios recommends a shortcoming in the apparatus or might be specialised issue diagnosed with the SPV plant to bring foreseen/expected electric energy. fundamental by and huge execution Ratio is the all round ordinary modern day dimension to decide the potential of a SPV plant. Intermittently the huge majority of the companions are surprisingly disturbing to gauge and determine the PR's of the diverse SPV vegetation for the duration of the globe, which may be located at contemplated without a doubt unique land locations [9-16].

\section{B. Debasement difficulty}

Debasement is a commercial enterprise enterprise affiliation time period this is applied to make clear the discount in yield strength of the SPV plant over a time period. The corruption mainly intentions in sun modules, inverters and Cables. All brought substances honestly corrupt, besides debasement price in all likelihood won't be 
uniform for all of the contraption utilized within the gadget. high entertainment activity must be drawn towards module corruption. due to the truth, sun modules are the full-size devices that advantage the solar light and changes over into DC first-class. on the off chance that the forums/modules debase at faster price, the yield power from the modules will bring down each day resulting in terrible strength yield for the remainder of existence time. as a very last product additional enthusiasm to be eager on pick out the elements first to expedient debasement expense. within the wake of making experience of the additives impacting the debasement, remedial actions ought to be intentional.

\section{OUTCOMES AND DISCUSSIONS \& RESULTS}

Sunlight primarily based Radiation esteems on the net web page online are assembled from the certainties to be had thru the NASA on the closest spot. The paintings area IV exhibits the month to month now not irregular solar illumination esteems at the internet net website web page for the years 2015 and 2016.

\section{TABLE.IV}

MONTH WiSe SOlar RAdiation VALUES FOR THE YEARS 2016 AND 2015 OF 20KW SPV PLANT

\begin{tabular}{|l|l|l|}
\hline $\begin{array}{l}\text { Month \& } \\
\text { Year }\end{array}$ & $\begin{array}{l}\text { Solar } \\
\text { Radiation } \\
\mathbf{2 0 1 6} \\
\mathbf{( k W h )}\end{array}$ & $\begin{array}{l}\text { Solar } \\
\text { Radiation } \\
\mathbf{2 0 1 5} \\
\mathbf{( k W h}\end{array}$ \\
\hline January & 158.4 & 154.7 \\
\hline February & 169.6 & 169.9 \\
\hline March & 178.9 & 184.9 \\
\hline April & 188.3 & 197.8 \\
\hline May & 201.1 & 201.7 \\
\hline June & 153.2 & 151.4 \\
\hline July & 140.4 & 169.3 \\
\hline August & 150.4 & 152.4 \\
\hline September & 111.6 & 149.5 \\
\hline October & 148.6 & 155.5 \\
\hline November & 139.7 & 153.2 \\
\hline December & 143.2 & 149.7 \\
\hline Average & 156.95 & 165.83 \\
\hline
\end{tabular}

Fig.3 shows the pictorial representation of the same data for the years 2015 and 2016 of $20 \mathrm{kWp}$ grid-tied solar PV plant on library building.

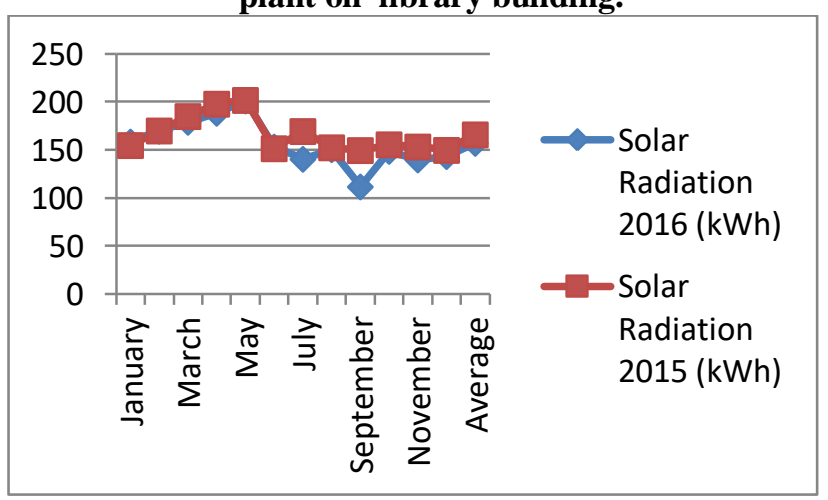

Fig. 3 Monthly Solar radiation values for the years $2015 \& 2016$ of $20 \mathrm{~kW}_{\mathrm{p}}$ SPV plant on rooftop of Library Block

\section{A. Computation of performance Ratio}

Desk V and desk VI show the decided month to month ostensible execution Ratio's of the SPV plant at STC situations for the three hundred and sixty five days 2015 and 2016 one at a time. all of the PR esteems are decided thru thinking of the at call plate information at STC circumstances (STC situations are 25o C of encompassing temperature, solar insolation of 1 thousand W/m2 and Airmass percentage 1.5). All assessed exhibition Ratio's at favored temperature conditions are otherwise called as Nominal regular execution Ratios.

Temperature rectified vast in popular execution share is getting well referred to as of overdue for higher examination. anyways, Nominal execution proportions are assessed and related in this appraisal.

Those month to month decided PR's are apparently and broke down to evaluate the debasement issue of SPV plant. vital truth to be visible right suitable here is plant yield is incessantly depending upon sun radiation contribution to the modules. in the event that the radiation is excessive, strength yield is probably radical and the other manner around. Assessing the plant debasement price simply utilising power yield may not offer affordable effects. For an incidence, from the Fig. three, for the term of the months July and September, sun radiation esteems are a decent association bounty extensively much less within the three hundred and sixty five days 2016 contrasted with 2015 . be that as it could, bearing on PR's are higher within the 12 months 2015 than in 2016. over the long haul, it's far continually higher to evaluate the overall execution Ratio's of the SPV plant than looking on the power yield.

TABLE.V

Month-Wise Average Actual ac Energy Generated, Average Theoretical DC Energy Could Generated at $25^{\circ} \mathrm{c}$ and Nominal PR of 20kw SPV Plant for the Year 2015

\begin{tabular}{|c|c|c|c|}
\hline Month \& Year & $\begin{array}{l}\text { AC Energy } \\
\text { Produced } \\
\text { Year } 2015\end{array}$ & $\begin{array}{l}\text { Theoretical } \\
\text { DC Energy } \\
2015\end{array}$ & PR2015 \\
\hline January & 2611.85 & 2782.92 & 93.85 \\
\hline February & 2787.53 & 3056.36 & 91.20 \\
\hline March & 2988.03 & 3326.20 & 89.83 \\
\hline April & 2929.68 & 3558.26 & 82.33 \\
\hline May & 2973.22 & 3628.42 & 81.94 \\
\hline June & 2262.63 & 2723.56 & 83.08 \\
\hline July & 2567.97 & 3045.57 & 84.32 \\
\hline August & 2365.32 & 2741.55 & 86.28 \\
\hline September & 2351.52 & 2689.38 & 87.44 \\
\hline October & 2588.20 & 2797.32 & 92.52 \\
\hline November & 2581.72 & 2755.94 & 93.68 \\
\hline
\end{tabular}




\begin{tabular}{|l|l|l|l|} 
December & 2518.12 & 2692.98 & 93.51 \\
\hline Average & 2627.15 & 2983.20 & 88.06 \\
\hline
\end{tabular}

TABLE.VI

Month-Wise Average Actual ac Energy Generated, Average Theoretical DC Energy Could Generated At $25^{\circ} \mathrm{c}$ and Nominal PR of 20kw SPV Plant for the Year 2016

\begin{tabular}{|l|l|l|l|}
\hline Month \& Year & $\begin{array}{l}\text { AC } \\
\text { Energy } \\
\text { Produced } \\
\text { Year 2016 }\end{array}$ & $\begin{array}{l}\text { Theoretical } \\
\text { DC Energy } \\
\mathbf{2 0 1 6}\end{array}$ & PR2016 \\
\hline January & 2606.70 & 2849.48 & 91.48 \\
\hline February & 2744.10 & 3050.96 & 89.94 \\
\hline March & 2791.40 & 3218.26 & 86.74 \\
\hline April & 2720.00 & 3387.36 & 80.30 \\
\hline May & 2788.50 & 3617.62 & 77.08 \\
\hline June & 2207.40 & 2755.94 & 80.10 \\
\hline July & 2063.50 & 2525.68 & 81.70 \\
\hline August & 2283.10 & 2705.57 & 84.39 \\
\hline September & 1720.40 & 2007.59 & 85.69 \\
\hline October & 2429.60 & 2673.19 & 90.89 \\
\hline November & 2314.10 & 2513.09 & 92.08 \\
\hline December & 2355.90 & 2576.05 & 91.45 \\
\hline Average & 2418.72 & 2823.40 & 85.67 \\
\hline
\end{tabular}

B. Calculation of Degradation Factor

TABLE.VII

Month Wise AC Energy Produced for the Years 2016 and 2015 af 20kw SPV Plant

\begin{tabular}{|l|l|l|}
\hline $\begin{array}{l}\text { Month \& } \\
\text { Year }\end{array}$ & $\begin{array}{l}\text { AC Energy } \\
\text { Produced in } \\
\text { Year 2016 }\end{array}$ & $\begin{array}{l}\text { AC Energy } \\
\text { Produced in Year } \\
\mathbf{2 0 1 5}\end{array}$ \\
\hline January & 2606.70 & 2611.85 \\
\hline February & 2744.10 & 2787.53 \\
\hline March & 2791.40 & 2988.03 \\
\hline April & 2720.00 & 2929.68 \\
\hline May & 2788.50 & 2973.22 \\
\hline June & 2207.40 & 2262.63 \\
\hline July & 2063.50 & 2567.97 \\
\hline August & 2283.10 & 2365.32 \\
\hline September & 1720.40 & 2351.52 \\
\hline October & 2429.60 & 2588.20 \\
\hline November & 2314.10 & 2581.72 \\
\hline December & 2355.90 & 2518.12 \\
\hline Average & 2418.72 & 2627.15 \\
\hline
\end{tabular}

\begin{tabular}{|l|l|r|l|}
\hline Month \& Year & PR 2016 & PR 2015 & $\begin{array}{l}\text { \% } \\
\text { Degradation }\end{array}$ \\
\hline January & 91.48 & 93.85 & 2.53 \\
\hline February & 89.94 & 91.20 & 1.38 \\
\hline March & 86.74 & 89.83 & 3.45 \\
\hline April & 80.30 & 82.33 & 2.47 \\
\hline May & 77.08 & 81.94 & 5.93 \\
\hline June & 80.10 & 83.08 & 3.59 \\
\hline July & 81.70 & 84.32 & 3.10 \\
\hline August & 84.39 & 86.28 & 2.19 \\
\hline September & 85.69 & 87.44 & 1.99 \\
\hline October & 90.89 & 92.52 & 1.77 \\
\hline November & 92.08 & 93.68 & 1.70 \\
\hline December & 91.45 & 93.51 & 2.20 \\
\hline Average & 85.67 & 88.06 & 2.72 \\
\hline
\end{tabular}

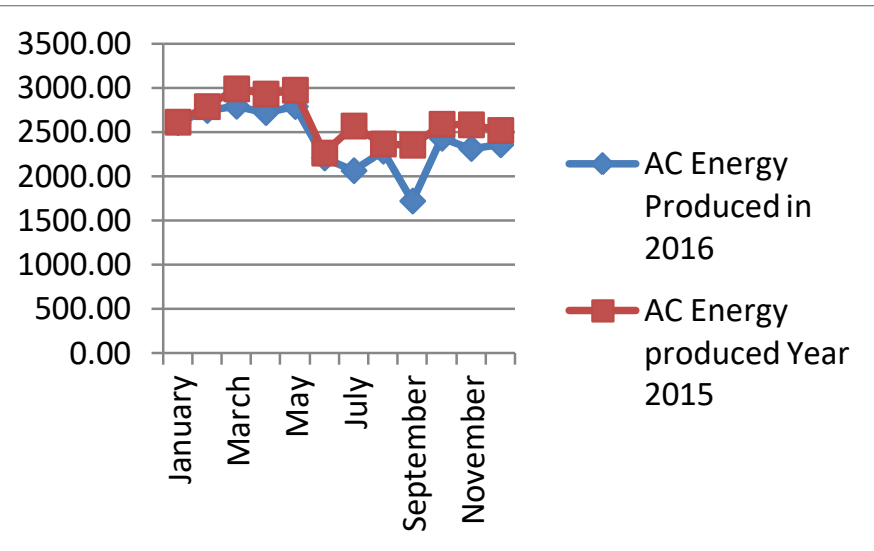

Fig.4 Monthly AC energies produced by the $20 \mathrm{kWp}$ SPV plant for the years $2015 \& 2016$

Table VII thinks about the AC power created by method for the utilization of the plant for the years 2015 and 2016. Fig. 4 demonstrates the graphical case of the indistinguishable. essentially, table VIII demonstrates the looking at the general execution proportion's the plant for the years 2015 and 2016. Fig.five speak to the graphical example of same measurements. From the charts, it's far distinguished that, the general by and large execution Ratio's of the SPV plant for the yr 2015 are imperceptibly higher than typical execution Ratio's for the yr 2016. q4 in the PR's is because of corruption in severa contraptions which is most likely utilized inside the device. On the off chance that the debasement inconvenience is even $1 \%$ with regards to an a year can likewise achieve unbalanced recompense span. Fig. 6 shows the bar outline case of the month-cunning rate corruption esteems [17].

TABLE.VIII

Month Wise Performance RatioValues for the Years 2016 and 2015 of 20kw SPV Plant 


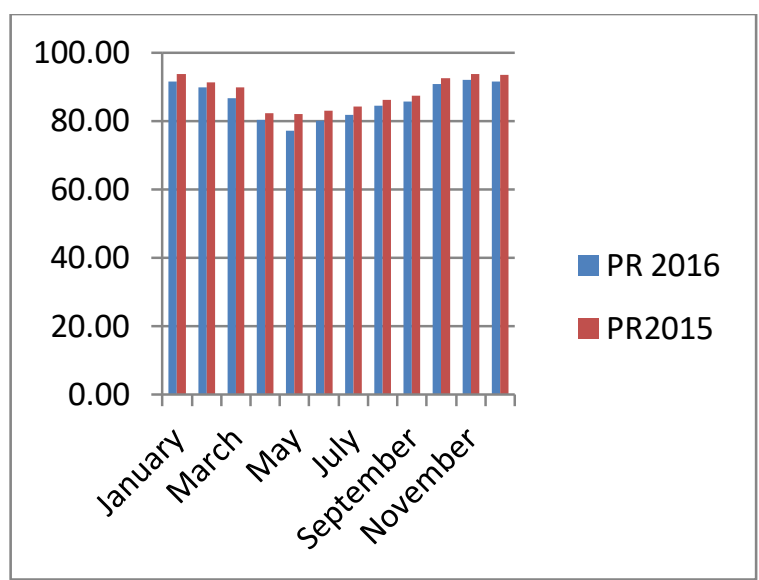

Fig.5 Monthly Performance Ratios of SPV plant for the years 2015\&2016

\section{Percentage Degradation}

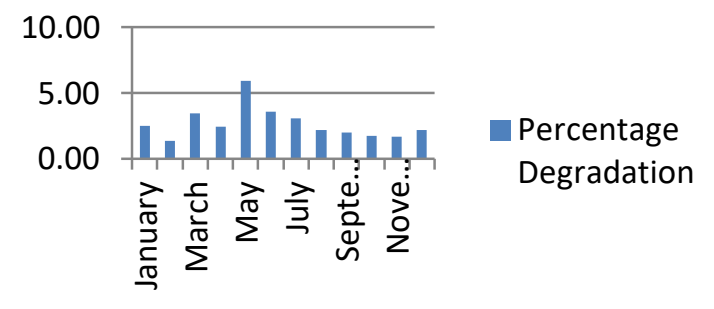

Fig.6 Monthly percentage degradation of $20 \mathrm{~kW}$ SPV plant on rooftop of Library Block from 2015 and 2016 PR data

\section{CONCLUSIONS}

On this exploration, the effect and consequences of rot element at the general by way of and large execution of $20 \mathrm{kWp}$ lattice - tied SPV plant at the housetop of Library of CVRCE is broke down from the 2015\&2016 plant information. in the heading of March to June, the corruption esteems are remarkably greater prominent as a result of blast in encompassing temperature notion methods more noteworthy power misfortunes at module level. The decided corruption additives are set to be minimal superior to foreseen esteems. the ones features have to be restricted by using approach for using taking valid measures for the unequalled everyday generally execution of the plant in angle on disintegration. it's far supported that modules ought to be dust-free. To gain this, sun PV boards wants to be wiped clean off in normal phrases every sooner than first light or after nightfall because of the truth the critical driver for corruption is put to be dust and soling at the forums. The best fee of the PR is analyzed within the long stretch of Jan 2015 with ninety 3.80 five\% and negligible well worth is located to be in may additionally furthermore in addition additionally 2016 with $77.08 \%$. subsequent to searching at the PR's of plant for the revolutionary years, the most severe corruption is located to be in may also furthermore moreover'16 in view of unreasonable surrounding temperature and residue occasions. Low debasement is analyzed negligible within the lengthy stretch of February'16 because of mild temperatures and espresso earth/dirtying situations. it is likewise put that the general plant ordinary execution is momentous as according with huge commercial enterprise fashions.

\section{REFERENCES}

1. Razykov TM, Ferekides CS, Morel D, Stefanakos E, Ullal HS, Upadhyaya HM. solar oriented photovoltaic power: present day status and destiny prospects. Sol strength 2011 eighty five: $1580 ; 1608$.

2. Ali Hajiah, T.k., k. Sopian, M. Sebzali1, performance of community related photovoltaic framework in locations in Kuwait, 2013, Kuwait Institute for scientific research (KISR): Kuwait. worldwide journal of Photoenergy volume (2012), Article identity 178175, p. 20.

3. S. Elhodeiby, H. M. B. Metwally, and M. A. Farahat, "Execution evaluation of $3.6 \mathrm{~kW}$ Rooftop Grid linked Photovoltaic system in Egypt," in lawsuits of global convention on electricity structures and technologies (ICEST 2011), Cairo, Egypt, 2011, pp. 151-157.

4. S. Singh, R. Kumar and V. Vijay, "Execution exam of $58 \mathrm{~kW}$ community related rooftop top sun based PV framework," electricity India global convention (PIICON), 2014 sixth IEEE, Delhi, 2014, pp. 1-6.

5. Yan S, Lai-Cheong C, Lianjie S, Kwok-Leung T. continuous expectation models for yield electricity and talent of matrix associated solar orientated photovoltaic frameworks. Appl Energ 2012; 93: 319;326.

6. Al-Sabounchi AM, Yalyali SA, Al-Thani HA. shape and execution assessment of a photovoltaic matrix associated framework in sweltering weather conditions. repair strength 2013; fifty three: seventy one;seventy eight.

7. Records sheet of REFUlog Inverters

8. Statistics sheet of Kohima strength Pvt Ltd.

9. Whitepaper on PR as opposed to CUF given by means of CHROSIS Sustainable solutions.

10. Padmavathi okay, Daniel SA. Execution exam of a $3 \mathrm{MWp}$ lattice related sunlight based photovoltaic energy plant in India. vitality Sustainable Dev 2013;17:615-25.

11. B.S.Kumar, ok.Sudhakar, performance of assessment of 10MW lattice associated Photovoltaic energy plant in India, energy reports 1(2015) 184-192.

12. Shukla, A.okay., Sudhakar, ok., Baredar, P., 2016a. duplicate and execution examination of $110 \mathrm{kWp}$ lattice associated photovoltaic framework for non-public structure in India: A relative investigation of different PV innovation. vitality Rep. 2, eighty two-88.

13. Shukla, A.okay., Sudhakar, okay., Baredar, P., 2016 b. structure, undertaking and monetary examination of impartial rooftop top sunlight based PV framework in India. Sol. energy 136, 437-449

14. Kamal Attari, Ali El Yaakoubi,Adel Asselman Comparative overall performance investigation among photo-voltaic structures from two awesome urban regions, tenth global assembly interdisciplinary in Engineering, Proceedia Engineering 181(2017) 810-817. Elsevier, reachable on www.sciencedirect.com

15. P.Rajesh Kumar, D.Koteswara Raju, Rajib Kumar Kar "Execution Metrics of Grid connected sun PV Plant on Roof pinnacle of CVR university of Engineering-A Case examine" journal of green Engineering Vol. 7, 99-128 - July 2017.

16. "Effect of Ambient temperature on execution of Grid-linked inverter delivered in thailand", komonpan, familiar diary of photograph energy,extent 2014, hindawi distributing.

17. Position of execution measurements to differentiate the Gaps in sun oriented strength age, P.Rajesh Kumar ,fourth global accumulating on electric vitality frameworks ICEES $2018 \mathrm{Feb}$ 2018 